\title{
Drug-induced notched T waves
}

\author{
T. A. C. de Vries · J. Seelig • R. Pisters - M. E. W. Hemels
}

Accepted: 25 January 2021 / Published online: 9 February 2021 (c) The Author(s) 2021

A 27-year-old man was admitted with a recurrence of atrial flutter. He had no other relevant medical history and had used $80 \mathrm{mg}$ sotalol as a "pill-in-thepocket' in addition to sotalol $80 \mathrm{mg}$ twice daily. His current (Fig. 1a) and previous electrocardiograms showed a normal QTc interval. Serum potassium levels were within the normal range. One milligram of ibutilide was administered intravenously, preceded by $750 \mathrm{mg}$ of intravenous magnesium as a precautionary measure.

An electrocardiogram recorded $5 \mathrm{~min}$ after ibutilide administration showed, aside from conversion to sinus rhythm, a prolonged QTc of $460 \mathrm{~ms}$ (from $390 \mathrm{~ms}$ ) and notched T waves in leads V2-V5 (Fig. 1b). Notched T waves are classically described in congenital long QT syndrome (LQTS) [1], especially in LQTS type 2 where these $\mathrm{T}$ waves are reported in $63 \%$ of cases [2]. LQTS type 2 is caused by loss of function of the KCNH2 ( $h E R G$ ) gene, which codes for the rapid delayed rectifier potassium channel $\left(I_{\mathrm{Kr}}\right)$ and plays an important role in the repolarisation of the myocardial cell. However, drugs not genetics-in particular

T. A. C. de Vries $(\bowtie) \cdot$ J. Seelig $\cdot$ R. Pisters $\cdot$ M. E. W. Hemels Department of Cardiology, Rijnstate Hospital, Arnhem, The Netherlands

TACdeVries@Rijnstate.nl

T. A. C. de Vries

Department of Cardiology, Amsterdam UMC, University of Amsterdam, Amsterdam Cardiovascular Sciences, Amsterdam, The Netherlands

J. Seelig

Cardiovascular Research Institute Maastricht (CARIM), Maastricht, The Netherlands

J. Seelig · M. E. W. Hemels

Department of Cardiology, Radboud University Medical

Centre, Nijmegen, The Netherlands class III antiarrhythmic drugs including sotalol and ibutilide-are the most common cause of interference with $I_{\mathrm{Kr}}$. Although less frequently documented, such drugs can also cause notched $\mathrm{T}$ waves $[3,4]$.

This case underlines the risks involved when multiple QTc-prolonging drugs are administered, even in those without other risk factors for QTc prolongation [5]. Granting that the usefulness of intravenous magnesium prior to ibutilide is uncertain, it is a simple strategy that may potentially prevent torsade de pointes. Our patient was discharged after $4 \mathrm{~h}$ of continuous monitoring during which no arrhythmias occurred. An electrocardiogram recorded 2 weeks after admittance confirmed the QTc interval had returned to normal (Fig. 1c).

Conflict of interest T.A.C. de Vries, J. Seelig, R. Pisters and M.E.W. Hemels declare that they have no competing interests.

Open Access This article is licensed under a Creative Commons Attribution 4.0 International License, which permits use, sharing, adaptation, distribution and reproduction in any medium or format, as long as you give appropriate credit to the original author(s) and the source, provide a link to the Creative Commons licence, and indicate if changes were made. The images or other third party material in this article are included in the article's Creative Commons licence, unless indicated otherwise in a credit line to the material. If material is not included in the article's Creative Commons licence and your intended use is not permitted by statutory regulation or exceeds the permitted use, you will need to obtain permission directly from the copyright holder. To view a copy of this licence, visit http://creativecommons.org/licenses/by/4.0/. 


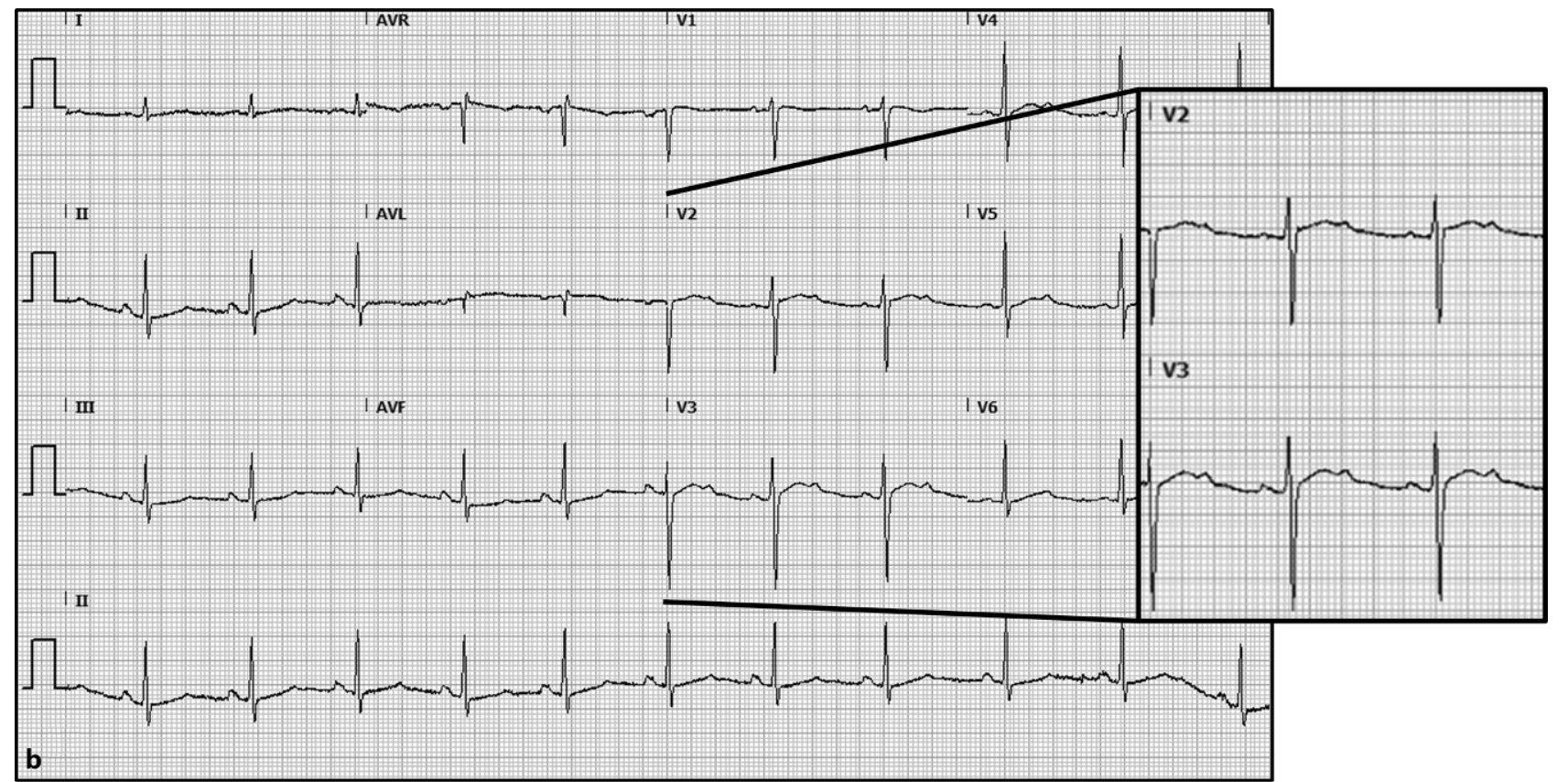

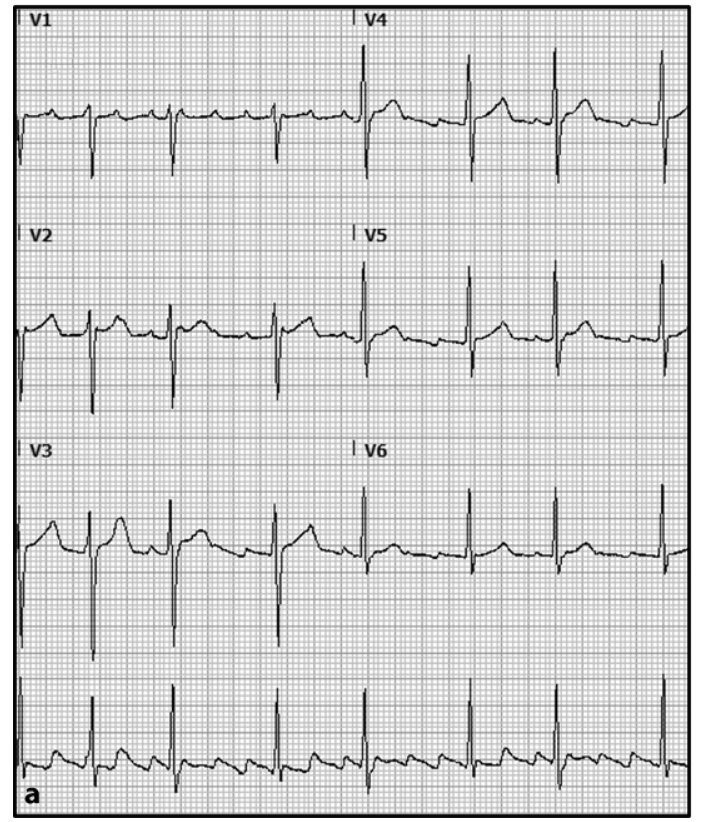

Fig. 1 a Electrocardiogram recorded before administration of ibutilide. A typical, counter-clockwise, atrial flutter with an alternating atrioventricular conduction block. b Electrocardiogram recorded $5 \mathrm{~min}$ after intravenous administration of ibutilide. Besides successful conversion to sinus rhythm, QTC

\section{References}

1. Schwartz PJ, Crotti L. QTc behavior during exercise and genetic testing for the long-QT syndrome. Circulation. 2011;124:2181-4.

2. Lupoglazoff JM, Denjoy I, Berthet M, et al. Notched T waves on Holter recordings enhance detection of patients with LQt2 (HERG) mutations. Circulation. 2001;103:1095-101.

3. Cubeddu LX. Drug-induced inhibition and trafficking disruption of ion channels: pathogenesis of QT abnormalities prolongation $(460 \mathrm{~ms})$ can be observed along with a positive deflection in the downward slope of the $T$ waves in leads V2-V5. c Electrocardiogram 2 weeks after admittance to the emergency department. The QTc interval has returned to normal (390 ms)

and drug-induced fatal arrhythmias. Curr Cardiol Rev. 2016;12:141-54.

4. Vicente J, Johannesen L, Mason JW, et al. Comprehensive $\mathrm{T}$ wave morphology assessment in a randomized clinical study of dofetilide, quinidine, ranolazine, and verapamil. JAmHeart Assoc. 2015;4:e1615.

5. Tisdale JE, Jaynes HA, Kingery JR, et al. Development and validation of a risk score to predict QT interval prolongation in hospitalized patients. Circ Cardiovasc Qual Outcomes. 2013;6:479-87. 